197

PHARMACOKINETICS OF MIDAZOLAM IN INFUSION FOR LONG-TERM STMATTON OF VENTILATDD PATIENIS IN TOU.

Alvarez $\mathrm{JA}^{*}$, Allegue $\mathrm{JM}^{*}$, Brugger AJf, Melgarejo $\mathrm{A}^{*}$, Fabregat $\mathrm{J}^{*}$ and Crespillo $\mathrm{J}^{* *}$.

Sedation is necessary to improve patient oomfort, ateruate the strees response and facilitate mechanical ventilation. Midazolam a water soluble benzodiacepine with a faster onset of action and a shorter elimination half-life than other drugs, has become popular and is now increasing its usage in the ICU setting. The aim of ar paper is the quantitation of plas itic concentration of Midazolem needed to obtain adequate sedation. Six patients who were due for ventilation for at least $24 \mathrm{~h}$., age $66 \pm 9$, weight $73 \pm 13$, Apache II index $23 \pm 5$, received one initial dose of Mida zolam $0.3 \mathrm{mg} / \mathrm{kg}$ followed $15 \mathrm{~min}$ after by continous infusion. During the first $24 \mathrm{~h}$ to facilitate mechanical ventilation, a initial bolus dose of the neuromuscular blocking drug Vecumonium $0.1 \mathrm{ng} / \mathrm{kg}$ were administered followed by continous infusion (abolition of the 30 or 40 response to ulnar nerve train of four supramaximal stimulation) during at least 24h. Determinations of Midazolam were carried out by extraction of 5 ml of bood, cen trifuged, plasma separated and stored deep-frozen until analysis. Blood samples were taken at the following intervals: pre dose $-2-5-15-30 \mathrm{~min}$ $1-2-4-8-12-24-36-48-60 \mathrm{~h}$. A sensitive and selective HPIC assay using UV de tection at $254 \mathrm{~mm}$ for quantitation was used. (Hewlett-Packard 1050 Autosampler, U-Bandapack columns $\mathrm{C} 18,10 \mathrm{um}$.). Pharmacokinetics paraneters we re calculated from each patient according to standand formulae. The data were fitted to a biconpartmental model using an own program besed on iterative methods.

Midazolam Infusion range was 30-16/A1 (mear 63h). During the initial bolus phase: $V_{d}$ cent. compart. $=233 \mathrm{~m} / \mathrm{Kg} . \mathrm{T} / 2 \alpha=6.5 \mathrm{~min}$ and Mean Residence $\mathrm{Ti}$ me $\left(T_{\text {res med }}=90 \mathrm{~min}\right.$. During the infusion phase: Clearance $=94 \mathrm{ml} / \mathrm{kg} / \mathrm{h}$ $V_{d}$ steady state $=109 \mathrm{nl} . \mathrm{kg}$. The mean plasma concentration for therapeutic window was $430 \pm 126 \mathrm{ng} / \mathrm{ml}$. At the end of infusion, recovery was obtained wi tha t antagonize in $53 \pm 26 \mathrm{~min}$.

Anesthesiology and Intensive Care Services. Hospital Rosell CARTACENA*. Pharmacology Department University MURCIAf. Control Quality Laboratories Roche S.A. MADRDD**.

\section{Cardiovascular assessment II}

\section{9}

THORACIC ELECTRICAL BIOIMPEDANCE (TEB) VS THERMODILUTION (TD) FOR CARDIAC OUTPUT (CO) MEASUREMENT DURING MECHANICAL VENTILATION

Rigoli A, Allaria B, Brunetti B, Defilippi G, Reina V, Sansone E.

TEB is a non-invasive technique for haemodynamic monitoring. Sone reports concern situations influencing the measurements performed with TEB, particularly in critically ill patients (pts) (sepsis, haematocrit variations and mechanical ventilation). In this study we compared $c 0$ measurements obtained with TEB and with TD in pts under mecharical ventilation. Co was measured before induction of general anaesthesia and about 10 minutes after orotracheal intubation and connection to ventilator. 17 pts (age 46-72, BSA 1.6-1.97 m2, haematocr it 30\%-40\%) were included in our study. All the pts underwent the sane $k$ ind of ventriation: 12 breaths/min with tidal volume $8-10$ $\mathrm{ml} / \mathrm{kg}$. Co measurements with TD were performed injecting $10 \mathrm{mil}$ of sal ine solution at room temperature. The recorded value is the average of three measurements. TEB data were recorded using a Bomed NCCOM3 device, considering the average of one minute recording. In non-ventilated pts the mean TO-CO was $5.96 \pm 1.29$ (SO) $1 / \mathrm{min}$ and the mean TEB-CO $5.77 \pm 1.52$. The equation is $y=1.059 x-0.537$ with $r=0.896 \quad(p<0.0001)$. In the same pts under mechanical ventilation the mean TD-CO value was $5.67 \pm 1.44$ $1 / \mathrm{min}$, while the mean TEB-CO was 5.8911.88. Thr equation is $Y=0.896 x+$ 0.813 . with $r=0.688(0<0.002)$. For a more accurate evaluation of the data we plotted the difference between the two measurements (TD-CO. IEB-CO) by mean CO (TD-CO + TEB-CO /2) as suggested by 8 land and Altman (Lancet, 1986). He obtained the following information: the mean difference between the techniques in non-ventilated pts was $0.18+0.16$, while in ventilated pts was $-0.22 \pm 0.33$. The co values measured using these two methods are similar; the differences are quite slight and there are no major variation for different flow levels. In ventilated pts the difference, though increasing, remains acceptable for clinical purposes. Only in one case the results of the two tectniques disagreed. Therefore it can be stated that, due to its easy use, non-invasivity, continuous data reading, and relatively low cost, IEB can be considered a useful technique for haemodymamic monitoring of critical pts.

Servizio di Anestesia e Rianimazione, Ospedale s.Corona, viale forlanini 12120020 Garbagnate, Milano, Italia
PROPOFOL versU: MIDAZOLAM IN SEDATION OF CRITICALLY ILL PATIENTS. COST-BENEFIT ANALYSIS

G.Carrasco. R. Molina. J Costa", J.M. Soler . J Paniagua, LI Cabre

Propolol (2,6-di-isopropylphenol) is an intravenous anaesthatic agent which has been tavourably compared with midazolam in continuous sedation of patients undergoing mechanical ventilation. Its use reduces the time needed for recovery of spontaneous respiration. One of the study has been able to demonstrate whether a possible reduction in length ICU stay in patients sedated with propofol would be of benefit in reducing the ecomorrical cost of such stays
The purpose of this study is to ovaluate and compare the sately, clinica! entects and economical cost of propotol and midazolam in the sedation of ICU patients undergoing mechanica!

ventilation.
One hundred-fitty critically ill patients were studled and randomly allecated to receive short-term (less than 24 hours). medium-term (24 hours.7 days) and protonged (more than 7 days) (n) Simplified Acule Physiotogic Score) and basal conscience levels (determined by the Glasgow Coma Score moditied by Cook). Mean duration of sedation with propolot (11.8 hours, 117 . i hours and 313.5 hours for the subgroups of short, medium and protonged-term sedation, respectively) was similar to that of subgroups traated with midazotam (11.7 hours, 1131 hours and 342.3 hours, respectively). Mean doses required were $2.36 \mathrm{mg} / \mathrm{kg} / \mathrm{hr}$ of propotol and $0.17 \mathrm{mg} / \mathrm{kg} / \mathrm{hr}$ of midazolam. Patients in the propotol group showed a percentage of sodation hours at the desired level of $93 \%$ compared with 82\% (p<0.05) in the midazolam group. No difterences between groups were observed with respect to
hemodynamics. O2 transport and a nalytical parameters. Both agents were considered sate with respect to the induction of adverse reactions during their use in prolonged sedation.

Aecovery atter interrepting gedation was significantly faster in patients treated with propofol (1.0*0.2, 2.8*1.0,5.2*2.1 hours for extubation, and $2.1 \neq 0.5,5.5 \pm 1.9,9.9 \pm 36$ hours tor total recuperation, for short-term, medium-term and prolonged-term sedation subgroups,

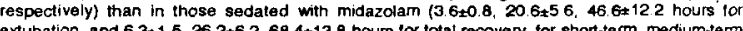
extubation, and $63 * 1.5,262+6,2,684 * 13$, hours for total recovery, for shon-term, mediumterm and probonged-term sedation subgroups, respectively). In patients sedated with propotol, total medium and prolonged-term sedation subgroups, respectively) while this conelation was nol

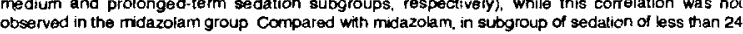
hours, propofol provided a cost-savings of approximately $1,900 \mathrm{pts}$ per, patient, due to shorter ICU stays. In the subgroup of more than 24 hours sedation. and compared with midazolam, propofol had the same quantifiable cost. but constituted a greater indrect benefit due to money saved on the cost
of antagonisation with fumazenil.

In our hospital environment, propolol is a sedative agent with the same safety, higher
ctinical effectiveness and befter cost-benefit ratio than midazolam in continuous sedation critically ill patients

Intensive Care Service SCIAS-Hospital de Barcelona. Diagonal 660,08034 Barcelona. Spain

\section{0}

OCIEPHINATION OF CAROIAC OUTPUT, OXYCEN CONSUMPTION AND DXYGEN DELIVERY

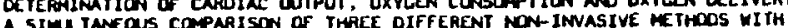
A sime incous cor

STMOWNo METHOOS:

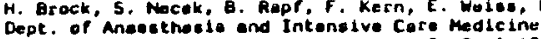

Depe. of Anabethesis and Intensive Core Medlcine, Chro Linz, Austrie Evelustion of oxygen tronsport verlebles cardiac output (C.O.), oxyoen

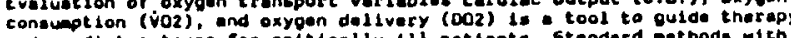
ond predict outcaes for critically 111 patients. Stenderd mothode with

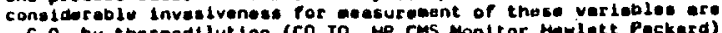
- C.O. by thereodilution (CO_TO, MP CHS Monlt or Hewlott Packard) Monitor)

ortertal ( $\mathrm{SaOZ}_{2} \mathrm{H}$ ) and alxed Vanous ( $5 \mathrm{NO2} \mathrm{H}$ ) oxygen suturation ind hesoglobin concentrat lon (Hib_H)

Metnods:

Inthio study the reliebllity of three different non-invastue cethods

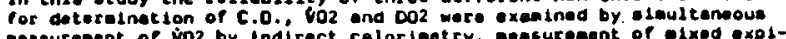

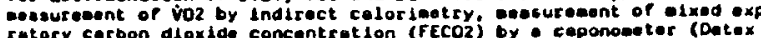
rutory cerbon doxide concentretlon (FECOz) by e ceponometer (Datex ted vont lletor (Evite, Orager). Oxygen soturations wore messured by

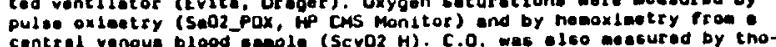

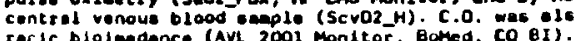

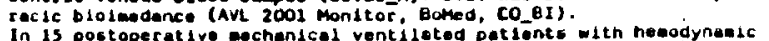
In 15 postoperative mochandcal ventileted petionts oith hemodynemic monitoring ineluding rediel ortery and puleomary ortery cotheters oll und celculated according to the foreule:

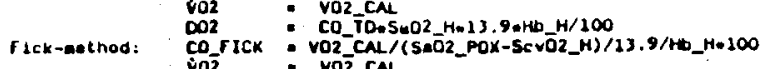

: VOZ

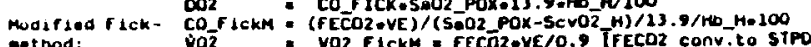

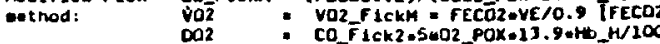

Broimpandence: c.0. $\quad \mathrm{CO} B \mathrm{OI}$

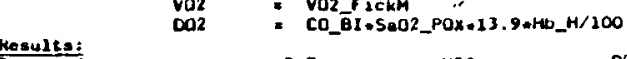

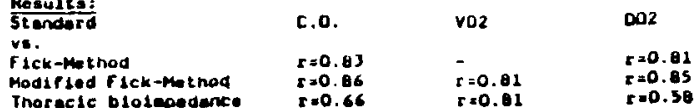
Conclueson: 002 by the flek-edthod ung ing indirect coloriaet $y$, pules oxlaetey and a centr.ven.blood emple and by Modirled fick-eptnod using cepnoastry und splrowetry as poll as pulso oxicetsy and e cuntr.ven.blood eapple. to be rel leblo ol tarnatives to thermodidution-derivad porametera. Thor 
201

ROLE OF TRAKSESOPHAGEAL ECHOCARDIOGRAPHY IN INTENSIVE CARE UNIT PATIENTS

M. Dan, R. Bondto*, F. Merlo, D. Pittarello*, L. Lacquaniti, L. Andriolo*.

In the last few years Transesophageal Echocardiography (TEE) has becowe an extremely helpfull tool for assessing cardiac function in critfealy fll patients. Nevertheless, in our opinion. TEE is underutilized in the intensive care setting because of lacking confidence in its potential benefits to solve clinical probleas. In order to evaluate the indications of TEE in a cultidisciplinary intensfve care unit, we revieved our four years experfence extrapolating all critically 111 patients not prevfousiy cubuitted.to cordloc diagnostic procedures. 78 patients underment 105.exaninations, the age range wes $17-82$ years and the velght range was $12-98$ kllos. Although the most frequent indication was monitoring left ventricular function and its phermacological support, other indications vere typically diagnostic. These included: unsatisfactory cardioc assessaent by tradtional monitoring 128 pts.l, unexplained hypotension 18 pts.), acute respiratory distress 17 pts.l, suspected aortic dissection 16 pts.1. systemic embolization 15 pts.). cardiac evaluation of donor patient $(5$ pts.). All TEE exaninations vere satisfactory for inaging. TEE was alvays the conclusive exeninatin when left ventricular function was under investigation, showing pitfalls and limitation of puloonary artery cateterization. In conclusions TEE may have great role in solving clinical problens at the bedside often avolding transport of the critically ill patients to the diagnostic laboratory. Consequently underutilization of this recent techniaue it is matter of difficult avallability of expensive equipment and trained personnel rather than lacking indteations in the intensive care unit setting.

Department of Anesthesio and Intensive Care, Hospital of Vicenza and University of Padova, 36100 Vicenza - ITALY -

\section{3}

THE PROGNOSTIC VALUE OF ATRIAL, PACIMG HANGRIP AND CORONARY RESERVE AFTER UNCOMPLICATED ACUIE MYOCARDIAL. INFARCTION.

A. Felices Nieto. J.M. Cruz Fernández. M. Pavón García J. Giménez Raureli. M.Guerrero de Mier. F.J.Ortega Vinuesa

We have studied the prognostic value of atrial pacing (AP) combined with hangrip exercise (APHG). It was performed in 66 consecutive patients 5 to 10 days (mean 6, 39 days) after uncomplicated acute myocardial infarction (UAMI).

Basal test was positive (depression of the ST gegment) in 33 patients ( 28 with AP and 5 with APHG). A second test after $1 \mathrm{mgr}$. of sublingual nitroglycerin shiftted negative in 13 patients for a similar or greater double product (present reserve) and continued being positive in 20 patients (absent reserve coronary).

During a follow-up of 12 months, 11 cardiac events had: 2 cardiac deaths, 3 recurrent myocardial infarction, 2 coronary by-pass surgery, 3 unstable angina and 1 heart failure.

Multivariate discriminant analysis indentified absent coronary reserve as the best predictor of morbimortality. It was able to classify to $80 \%$ of all patients for combined cardiac events and $83 \%$ for hard cardiac events. With help of ejection fraction, accuracy was of $93 \%$ for hard cardiac events.

Thus, our results showed that atrial pacing combined with handgrip exercise and coronary reserve, evaluated by vasodilator, were a usefull means of classifying patients at the time of Coronary Unit discharge after UAMI according to the likelihood of having cardiac events during the ensuing 12 months.

Intensive Care Unit. University Hospital Valme. Carretera de Cádiz $S / N$. Sevilla $(41014)$. España.

\section{2}

FREQUENCY OF BACTERIEMIA ASSOCIATED WITH TRANSESOPHAGEAL ECHOCARDIOGRAPHY (TEE) IN INTENSIVE CARE UNIT (ICU) PATIENTS (pts). H. Mentec*, S. Terré, and P. Legrand.

In cardiologic pts, the incidence of bacteriemia during TEE has been shown to be low enough (1.4 to $3.2 \%$ ) to avoid antibioprophylaxis. ICU pts might be at higher risk of bacteriemia because of widespread colonization of upper gastrointestinal tract with potentially pathogenic microorganisms and mucosal injuries due to instrumentation. To determine the infectious hazard associated with TEE in ICU pts, we conducted a prospective study in 89 pts (mean age 57). Blood samples were systematically drawn for aerobic and anaerobic culture before (BC1), at the end of (BC2) and $30 \mathrm{mn}$ after (BC3) TEE examinations in ICU pts. The mean duration of TEE was $39 \mathrm{mn}$ (15120). Eighty six pts were on ventilator, 78 had a nasogastric tube. Thirty pts had underlying conditions that usually justify antibioprophylaxic of bacterial endocarditis before high risk procedures such as gastrointestinal endoscopy. Twenty six pts did not recelve any antlbiotic at the time of TEE. In 76 pts, the Twenty six pts did not recelve any antibiotic at the time of TEE. In 76 pts, the
three BC were negative. In one pt. BC1 grew Enterococcus faecalis, BC2 and BC3 were sterile. In one pt, the three BC grew Staphylococcus aureus and $\mathrm{BC}_{1}$ also yielded Enterobacter cloacae. A contamination (only one positive $B C$ out of the three) with coagulase negative staphylococcl occurred in $2 \mathrm{BC} 1,3 \mathrm{BC} 2$, and $4 \mathrm{BC}$. In one pt treated with cefotaxime and netilmicin, $B C 1$ was sterile and $B C 2$ and $B C 3$ yielded coagulase negative staphylococci. In one pt recelving no antibiotic, $\mathrm{BC} 1$ was sterile and $\mathrm{BC} 2$ and $\mathrm{BC} 3$ yielded Enterococcus faecalis. None of these last two pts then received a specific antibiotic treatment nor developed any bacterial determination. Thus, the overall frequency of bacteriemia induced by TEE was $2.2 \%(2 / 89)$. The frequency did not differ whether the pts received antibiotics before TEE $(1 / 63,1.6 \%)$ or not $(1 / 26,3.8 \%)$ (NS). Therefore, antibioprophylaxis does not appear justified before TEE in ICU pts.

Departements of Medical Intensive Care Unit and Microbiology, Henri Mondor Hospital 94010 CRETEIL CEDEX FRANCE

EARLY RECURRENT ISCHEMIA EVALUATED WITH HOLTER.

L.Fayos, J.A .Lopez, J.E.Belenguer, R.oltra, A .Cabadés , M .Ruano,V.Palacios, J.M.Palencia. (ICU Hospital "LA FE. Valen cia).

The incidence, characteristics and prognostic significan ce of early ST-changes after acute myocardial infarction (AMI) evaluated with Holter monitoring are not well established.

We have stidied prospectively 83 patientes with AMI, Ki11ip class $I$ and $I I$, all under 65 years of age (53.6 9.1) The site of the AMI was anterior in 35 and inferior in 48. The maximum mean value of CPK was $1830230 \mathrm{U} / \mathrm{L}$. 56 patients received thrombolytic therapy (group T). Holter was performed for 48 hours, with 2 leads to detect local and at distance ischemia, on the 20 and 30 day of the AMI. The rise or depression of the ST-segment according to the $1 \times 1 \times 1$ rule were accepted as criteria of posi tivity $(H+)$ in the absence of previous tachycardia and/ox postural changes. A coronariography was performed in the two first weeks post-AMI. Death, reinfarction, need of aorto-coronary By-pass or PTCA were considered as criteria of adverse outcome.

$H+$ was observed in the $31.1 \%(26 / 83)$ of cases (15 in the zone of AMI, 6 at distance and 5 in both). A rise in the sT was observed in 15 cases, a depression in 6 and both in 5. Early post-AMI angina occurred in 22.9\% (19/83), $13 / 26$ (50\%) of $\mathrm{H}+$ and $6 / 57$ (10.5\%) of $\mathrm{H}-(\mathrm{p} 0.001)$. An adverse outcome was observed in 14/26 (53.8\%) of $\mathrm{H+}$ and in 6/57 (19.2\%) of $H-(p$ 0.01). Multivessel lessions occurred in 15/26 (57.6\%) of $\mathrm{H}+$ and in 24/57 (42\%) of H- (N.S.).

There were no significative differences in incidence of early angina and $\mathrm{H}+$ between the group $\mathrm{T}$ (19.6\%,30.3\%) and the group no $T(29.6 \%, 33.3 \%)$.

We conclude that Holter detected early ST changes postAMI is a frequent finding associated with early post-AMI angina and adverse otcome. Multivessel disease and thrombolysis don't appear to affect its incidence. 